\title{
Are Young Consumers Still Susceptible to the Country-of-Origin Effect?
}

\author{
Alexander Josiassen \\ Victoria University, Australia
}

\begin{abstract}
The effect that consumers' country-related images have on their purchase decisions is known as the country of origin effect. Marketing researchers have thoroughly investigated Country-of-Origin (COO) effects in a range of contexts since the mid-1960s. However, since the 1980s it has been thought (e.g., Levitt 1983; Ohmae 1995) that consumer needs and wants are converging and that nation-states are artificial and superficial entities of little value to consumers indicators of product quality. The argument is that since young consumers are used to seeing products from a variety of countries they do not have the country biases that the COO effect stipulates (Usunier 2006). A recent study (Wong et al. 2008) on young Chinese consumers and the COO effect appears to confirm that young consumers are no longer influenced by the COO effect. The aim of this research was to conceptually investigate how the relationship between young consumers' product-country image and their product evaluations is influenced by two contextual variables: their product involvement and their perceived product-origin congruency.
\end{abstract}

\section{Keywords}

Country-of-Origin, marketing research, value to consumers, young consumers.

\section{Introduction}

American Coca-Cola and IPod, Mexican Corona, and Australian Billabong are all examples of companies that appeal to a global youth culture while celebrating their national heritages. Since Schooler's (1965) seminal article the effect of country-of-origin (COO) biases on consumer purchase behaviour has been an issue of continuing interest. Over the past four decades the attention of researchers in this area has continuously shifted as new challenges presented themselves (Josiassen and Karpen 2007). A key challenge is the investigation of potential variables that moderate the influence of COO (Eroglu and Machleit 1989; Laroche, Papadopoulos, Heslop and Mourali 2005). Researchers have traditionally been interested in the influence of product involvement (Ahmed, Johnson, Yang and Fatt 2004; d'Astous and Ahmed 1999) and in recent years it has been suggested that perceived product origin incongruence may significantly reduce the importance consumers place on the $\mathrm{COO}$ cue (Chao 2001).

The influence of these moderators, however, on young consumers' purchase behaviour is unclear. The

Copyright (C) 2009 Victoria University. This document has been published as part of the Journal of Business Systems, Governance and Ethics in both online and print formats. Educational and non-profit institutions are granted a nonexclusive licence to utilise this document in whole or in part for personal or classroom use without fee, provided that correct attribution and citation are made and this copyright statement is reproduced. Any other usage is prohibited without the express permission of the importance of this particular market segment to marketers is well-documented as young consumers typically drive brand growth and success (Morgan 2007). The present-day young consumers are young in an era where multi-origin market offerings are more pronounced than any other generation has experienced (Wong, 
Polonsky and Garma 2008). Prominent researchers have even suggested (Levitt 1983; Ohmae 1995) that consumer needs are converging and that younger consumers therefore ignore regional and national differences. This perspective is supported by recent insights investigating the $\mathrm{COO}$ effect in the context of young Chinese consumers: "In targeting young consumers it appears that globalization leads consumers to believe that the world is converging and becoming one "country"" (Wong, Polonsky and Garma 2008, p. 469).

The present research conceptually explores two issues: Firstly, whether a COO effect can be found in the context of young consumers, and secondly whether product involvement and product origin congruency influence the effect of young consumers' COO-image on their product evaluations. This remainder of the paper is organised as follows: First, the theoretical area is introduced, and then two propositions are developed and forwarded. Finally, the article concludes with a discussion.

\section{Conceptual Background}

Since Schooler's (1965) seminal article the effect of country-of-origin (COO) biases on consumer attitudes has been an issue of continuing interest. Over the past four decades the attention of researchers has continuously shifted as new challenges presented themselves. Focus has shifted from looking for simple demographic explanations to origin biases, over a search for reasons why consumers often prefer domestic products to also include research on products with multi-national origin.

While researchers have studied this topic for more than 40 years now, and while there are more than 1000 articles printed in this area, the area is seen as a stale and uninteresting area by many researchers. In contrast, many practitioners tell us that origin plays a vital part in how businesses act and perform (e.g. Colyer 2005). Consequently, it seems that the academic literature does not sufficiently provide sophisticated normative guidelines for the management of $\mathrm{COO}$ and this state of affairs may lead to management by gut feelings or personal experiences.

The strategic use and limitations of origin management remain unclear (Beverland and Lindgreen 2002). While companies have a wide array of tools for managing their brand images, the set of tools for managing origin images is still rather crude. A rule of thumb such as "products from developed countries should emphasize "made-in" and charge a premium price while products originating from developing countries should focus on brand image and a value pricing" (Mohamad, Ahmed, Jr and Tyebkhan 2000) is overly simplistic and would result in wrong decisions for a wide portion of productcountry combinations. The result of the limited set of tools which is available to practitioners, is that origin-image management is based on anecdotes and crude advice that does not stem from a holistic framework of $\mathrm{COO}$ effects. Consequently, organizations lack the tools to manage the most basic image they have.

The perception of the area as problematic has not emerged because it is not important, but rather because there is still a disappointingly large divide between the area's potential contribution and the actual contribution that has been made. With a history stretching more than 40 years, many incremental steps shedding light on the area have been taken. Some bigger than others and while the criticism is understandable, there has been a continuing progress in knowledge advancement.

The following section of the paper is loosely based on the historical method. A historical account of how knowledge has advanced can often help to see future trends or remaining gaps (Low and Fullerton 1994; Nevett 1991).

\section{Historical Trends in Country-of-Origin Research}

From the published literature in origin research we identify nine significant milestones. These milestones which are summarized in Table 1 have all shaped the directions that research in this area has taken for the past 40 years. While they have had a large impact, they are by no means the exclusive forces behind the accumulation of knowledge that we have seen in this period. Several literature reviews have been 
conducted over the last 40 years and this paper can be seen as an extension of these significant efforts (e.g. Baughn and Yaprak 1993; Bilkey and Nes 1982; Ozsomer and Cavusgil 1991; Papadopoulos and Heslop 2002). Several researchers, such as John Darling, Charles Lillis, Chem Narayana, Nikolas Papadopoulos, Louise Heslop, Erdener Kaynak, Paul Chao and recently authors like George Balabanis, Adamantis Diamantopoulos and Peeter Verlegh, who are not mentioned among the nine milestones, have nonetheless made important contributions.

Table 1

Nine Major Milestones in Country-of-Origin Research

\begin{tabular}{|l|l|l|l|}
\hline & Year(s) & Author(s) & Key Contributions \\
\hline 1 & 1965 & Robert Schooler & Initial article published in the area \\
\hline 2 & $1970 / 77$ & Akira Nagashima & $\begin{array}{l}\text { Development of the semantic differential } \\
\text { scale }\end{array}$ \\
\hline 3 & 1982 & Warren J. Bilkey and Erik Nes & The first literature review \\
\hline 4 & $1984,85,89$ & Johny Johansson et al. & Multivariate studies \\
\hline 5 & 1987 & Shimp and Sharma & $\begin{array}{l}\text { Construction of the CETSCALE to } \\
\text { measure consumer ethnocentrism }\end{array}$ \\
\hline 6 & $1990 / 92$ & $\begin{array}{l}\text { C. Min Han et al. and Martin S. } \\
\text { Roth and Jean B. Romeo }\end{array}$ & $\begin{array}{l}\text { Focus } \text { on the interaction between } \\
\text { products and } \text { origin images }\end{array}$ \\
\hline 7 & $\begin{array}{l}1986 \text { and } \\
\text { onwards }\end{array}$ & $\begin{array}{l}\text { Attila Yaprak, Ravi } \\
\text { Parameswaran and R. Mohan } \\
\text { Pisharodi as well as Eugene D. } \\
\text { Jaffe and Israel D. Nebenzahl }\end{array}$ & $\begin{array}{l}\text { Identification and application of } \\
\text { country-of-origin facets }\end{array}$ \\
\hline 8 & $\begin{array}{l}1998 / 02 \\
\text { Jill Klein and co-authors }\end{array}$ & $\begin{array}{l}\text { The introduction of the animosity } \\
\text { construct }\end{array}$ \\
\hline 9 & $\begin{array}{l}1980 \mathrm{~s} \\
\text { onwards }\end{array}$ & $\begin{array}{l}\text { Laroche, Eroglu, Machleit, } \\
\text { Josiassen, d'Astous, Chao, Phau } \\
\text { and others. }\end{array}$ & $\begin{array}{l}\text { Focus } \text { on contingency variables which } \\
\text { explain previous variation in COO } \\
\text { findings }\end{array}$ \\
\hline
\end{tabular}

Schooler (1965) is often considered to be the article which initiated the interest into origin research. Schooler (1965) discovered differential effects based on the country of origin. Specifically, it was discovered that consumers in the Central American Common Market attributed certain characteristics to products from the other member countries based on their origin country.

The second milestone was set when Nagashima $(1970,1977)$ adjusted and employed the semantic differential method, developed by Osgood (1955), to this area. Since then this method has been used widely in origin research. Nagashima's two studies allowed him to make another important suggestion. Namely, that origin images can change over time.

The article by Bilkey and Nes (1982) is the third milestone. The authors pointed out several key weaknesses in past research and their article marks an important point in time that affected the research design of much subsequent $\mathrm{COO}$ research. This article is still today the most cited article in this area. The key suggestion was that so far almost all the studies in this area had been carried out by asking the respondents about their views on one single cue - country of origin. Bilkey and Nes claimed that studies that include only a single cue are likely to overestimate the effect of this single cue. This finding was known already from research on price-quality relationships, where price is consistently found to be a quality indicator, but where the effect is only high as long as price is the only other cue (Olson 1977). They recommended that future research should employ multiple cues so that the focal cue, country of origin, is less likely to be overestimated.

\footnotetext{
${ }^{1}$ A semantic differential scale is a bi-polar scale using adjectival opposites.
} 
After almost 20 years of mostly descriptive studies, Johansson and his co-authors carried out several multivariate studies. They adopted multi cue designs based on Bilkey and Nes' suspicions that single cue studies would overestimate the differential effects of the origin cue (1989; Johansson 1998; Johansson, Douglas and Nonaka 1985; Johansson and Nebenzahl 1986; Johansson, Ronkainen and Czinkota 1994).

The fifth milestone concerned the construction of the CETSCALE (Shimp and Sharma 1987). The CETSCALE measures the positive bias consumers may have towards domestic products. The CETSCALE has been widely used since and the existence of a home country bias has been confirmed repeatedly (Balabanis and Diamantopoulos 2004; Balabanis, Mueller and Melewar 2002; Chao, Wuhrer and Werani 2005; Kamaruddin, Mokhlis and Othman 2002; Kaynak and Kara 2002; Moon 2003; Moon and Jain 2001; Sharma, Shimp and Shin 1995) .

At this point in time several articles had noted that origin images may be product class or category dependent (Eroglu and Machleit 1989; Johansson, Douglas and Nonaka 1985). Han (1989) tried to explain some of the possible mechanisms behind this. Specifically, Han (1989) posited that the consumer may make sense of product images and country images in two ways. Either as a summary construct (a bias towards products based on prior experience with products from this country) or as a halo construct (a bias towards products based on the image of the country). Another important article that shed light on the product/country interface was the article by Roth and Romeo (1992). Roth and Romeo (1992) argue that consumers have some product characteristics they value more than other product characteristics depending on the product category. The idea is that the consumer looks for a fit between; a) the product characteristics that the consumer values in this particular product category and b) the product characteristics that the consumer believes the country is good at providing. This will result in either a fit or a misfit, with either being a favorable (fit along dimensions deemed important) or unfavorable (fit along dimensions deemed unimportant). This period of focusing on product/country interplay is the sixth milestone.

The seventh milestone relates to the disintegration of the origin image construct into its parts. Yaprak, Parameswaran and Pisharodi have published a series of articles developing and boundary testing a multi-dimensional measure of origin image (Parameswaran and Pisharodi 1994, 2002; Parameswaran and Yaprak 1987; Pisharodi and Parameswaran 1992, 1999; Yaprak and Parameswaran 1986). The dimensions or sub constructs are: 1) The general country image, 2) the product specific country image and 3) the brand specific country image. The authorship of Jaffe and Nebenzahl and co-authors look at another dimensionality of the origin image construct. They argue that many products have more than one origin; the product may for instance be designed in one country and manufactured in another. These divisions still play important roles in current research.

The eighth milestone refers to the initial animosity research. Klein et al argue that some consumers have a negative bias towards other countries and that this negative bias can affect their attitudes towards products from these countries (Klein, Ettenson and Morris 1998). An empirical test showed that some Chinese consumers do have such a negative bias towards products from Japan because of animosity towards Japan. Klein's (1998) initial animosity article is one of the most cited newer articles in origin research (e.g. Balabanis, Diamantopoulos, Mueller and Melewar 2001; Kaynak and Kara 2002; Klein 2002; Wong, Rindfleisch and Burroughs 2003)

The ninth milestone refers to the focus on contingency variables which moderate the COO effect. Several researchers (e.g. Eroglu and Machleit 1989; Laroche, Papadopoulos, Heslop and Mourali 2005) have proposed that the competing conclusions seen previously in $\mathrm{COO}$ research are the result of context-specific factors that moderate the importance of $\mathrm{COO}$ image during product evaluations. In this regard, studies in international marketing have pointed to the influence of two context-specific factors in particular: product familiarity (Eroglu and Machleit 1989; Josiassen, Lukas and Whitwell 2008; Laroche, Papadopoulos, Heslop and Mourali 2005) and product involvement (e.g. Ahmed, Johnson, Yang and Fatt 2004; d'Astous and Ahmed 1999). 


\section{Proposition Development}

\section{Product Involvement}

Product Involvement in this study refers to "[...] the general level of interest in the object or the centrality of the object to the person's ego structure" (Day 1970, p. 10). Studies that try to determine the effect of $\mathrm{COO}$ image on consumers' product evaluations almost exclusively rely on highinvolvement products (Phau and Prendergast 2000). Not only have very few studies examined whether the COO effect is salient for low-involvement products (Ahmed, Johnson, Yang and Fatt 2004), but "[t]here is no one study which explicitly compares both levels of involvement" (Phau and Prendergast 2000, p. 162). Consequently, researchers call for COO research to further examine the role of product involvement (e.g. d'Astous and Ahmed 1999; Pharr 2005; Phau and Prendergast 2000).

While competing views have existed on the influence of product involvement, the Product-InvolvementWeakens-the-COO-Effect (PIWCE) perspective (Josiassen, Lukas and Whitwell 2008) has become the dominant view. The PIWCE perspective on the contingency effect of product involvement is grounded in the literature on the Elaboration Likelihood Model (ELM) used in persuasion research. The ELM predicts that consumers go through either a 'central' or a 'peripheral' route to persuasion (Haugtvedt, Petty and Cacioppo 1992; Petty and Cacioppo 1984; Petty, Cacioppo and Schumann 1983). When consumers utilize a central route they exert the necessary cognitive effort to evaluate the information available to them. In contrast, consumers that utilize a peripheral route tend to base their evaluation on a more superficial analysis; typically, they employ salient and readily accessible cues. In general, the ELM posits that consumers will use a central route under high involvement circumstances and a peripheral route under low involvement circumstances (Petty, Cacioppo and Schumann 1983).

Drawing on the findings from persuasion research some COO-image studies (e.g. Han 1989; Maheswaran 1994) suggest that consumers rely more on COO information when they are less involved in the product category because $\mathrm{COO}$ image acts as a salient and accessible proxy on which to base a buying decision. Rather than being merely another piece of information, the COO acts as a stand-in for other product information.

Gurhan-Canli and Maheswaran (2000) propose, therefore, that when consumers consider a low involvement product, $\mathrm{COO}$ image is likely to be an important part of the information on which they base their product decisions. Verlegh et al. (2005, p. 128) conclude that: "country of origin has a greater impact on product evaluations when consumers are less motivated to process available information, for example when involvement is low." On the other hand, some researchers argue that country-of-origin image is stronger in high involvement contexts (Ahmed and d'Astous 1999; Ahmed, d'Astous and Eljabri 2002; Ahmed, Johnson, Ling, Fang and Hui 2002; Ahmed, Johnson, Yang and Fatt 2004). However, recent research (Josiassen, Lukas and Whitwell 2008) has confirmed that for the general consumer, country-of-origin image has a stronger effect on product evaluations when the consumer is less involved. Do 21 year-old Freya and 26-year-old Anastasia warrant being investigated separately from, for example, 31 year-old Patricia, 44 year-old Roy and 44 year-old Kirsten? Extant research on young consumes show that this demographic segment should be scrutinized separately. Young consumers (18-26 years of age) have a tendency towards higher product involvement than older consumers do (Strizhakova, Coulter and Price 2008) and the present study suggests that a differential effect of product involvement can be confirmed among young consumers. Thus:

\section{$P_{1}$ : For young consumers, the relationship between country-of-origin image and product evaluation is weaker with increasing product involvement.}

\section{Product Origin Congruency}

In a market place with increasing global sourcing, products often originate in more than one country (e.g. designed in country $\mathrm{X}$ and manufactured in country $\mathrm{Y}$ ). Product origin congruency refers to the level of congruency between these different origins. These product origin facets have only come into 
prominence in the COO literature in recent years (e.g. Li, Murray and Scott 2000) and an increasing amount of $\mathrm{COO}$ studies recognize the mounting presence of multi-origin products. An experiment (Chao 2001) indicates that product origin congruency may have an influence as to how consumers evaluate products.

The theoretical underpinning for congruency effects was first proposed by Osgood and Tannenbaum (1955). The congruency effect postulates that because incongruent information creates dissonance, congruent information will be preferred and relied on to a greater extent. Information is more congruent when more sources of information point in the same direction (Chao 2001). If, for instance, a high quality brand is sold in a high quality outlet, then those two indicators of quality would be congruent. If, on the other hand, the brand was sold in a low-quality outlet, such as a discount store, then the two quality indicators would be incongruent.

The congruency effect is well researched in the marketing literature. For example, congruency between a celebrity endorser and the type of product has been found to follow the congruency principle (Friedman and Friedman 1979; Kamins 1990; Misra and Beatty 1990). Leclerc et al. (1994) found that incongruence between foreign branding (perceived origin based on the brand name) and supplied actual origin information diminished the effect of the foreign branding effort itself.

Chao (2001) in an experiment constructs a low congruency setting and a high congruency setting. Based on the results, Chao (2001) suggests that product origin congruency may enhance the importance of COO image in consumers' product evaluation. This study extends Chao's (2001) experimental work in a survey setting while purposefully focusing on the youth segment.

A supporting theoretical argument can be drawn from self-concept theory (Sirgy 1982, 1985, 1986) which argues that consumers strive to achieve congruency between their actual and ideal selves. The image congruency hypothesis (e.g. Hong and Zinkhan 1995) further suggests that consumers utilize products to express themselves, and products that they see as matching their ideal self (ideal congruence) will be more favourably judged. The present study argues that young consumers strive for self-image congruency to at least the same extent as the general consumer. Thus, the following proposition is forwarded:

\section{P2: For young consumers, the relationship between country-of-origin image and product evaluation is stronger with increasing product origin congruency.}

\section{Discussion}

This study proposes that young consumers' COO image has a different effect on their product evaluations depending on the context. Specifically, it is proposed that consumers' reliance on COO image when evaluating a given product is contingent on product involvement. In addition, less involved young consumers are thought to depend more on $\mathrm{COO}$ image than will more involved young consumers. This supports the notion that COO image acts mainly as a proxy. When consumers are less involved in a given product category, they will rely more heavily on relatively fewer cues, such as COO (GurhanCanli and Maheswaran 2000; Han 1989). However, this does not imply that COO image is unimportant for high-involvement products.

Finally, the article proposes that young consumers rely considerably more on the $\mathrm{COO}$ cue when the product origin facets are perceived as congruent. Higher perceived product origin congruency would increase the perceived reliability of the $\mathrm{COO}$ image held by consumers. As a consequence this image may be used more when evaluating products and considering a purchase. In other words, when young consumers consider a product from a higher image product-origin, the positive relationship between $\mathrm{COO}$ image and product evaluation is strengthened the more the consumer perceives that the product origins are congruent. 


\section{Practical Implications and Future Research}

Unlike recent research in the context of young Chinese consumers (Wong, Polonsky and Garma 2008), we suggest that young consumers differentiate between product offerings from different countries. As such, it is proposed that Levitt's (1983) predictions about one global market according to which nation states are meaningless in terms of forecasting the quality of products, have not materialized in the market place. Rather, the study suggests that the COO effect plays a significant role in young consumers' purchase behaviour.

The article proposes that young consumers' product involvement weakens the influence of their COO image on product evaluations. As such, the influence of $\mathrm{COO}$ image would be higher for those young consumers who are less involved with the product than consumers who are more involved with the product. In addition to augmenting our knowledge of the conditions under which COO image is more or less salient, this research is an extension of work which aims to examine the role of the various facets of COO (Ahmed and d'Astous 2004; Chao 2001; Josiassen, Lukas and Whitwell 2008; Kleppe, Iversen and Stensaker 2002; Laroche, Papadopoulos, Heslop and Mourali 2005; Li, Murray and Scott 2000). The study builds on and extends previous research (Josiassen, Lukas and Whitwell 2008) on the interacting role of product familiarity as well as extant experimental research (Chao 2001) regarding the influence of product origin congruency. This is one of the first COO-studies to purposefully focus on young consumers purchase behaviour. It is the first study to conceptually investigate the roles of involvement and congruency in the context of young consumers. The research is important as the proposed contingencies are key variables that differentiate young consumers. In addition, studies on the $\mathrm{COO}$ effect have found insignificant or even contradictory results (Pappu, Quester and Cooksey 2006) and thus the present research promotes a contingency approach . This understanding will help advance international marketing theory and may help explain inconsistent prior findings.

For marketers, COO image is an important tool for influencing product attitudes and behaviour (Winter 2004). This study argues that despite the technological developments over the recent decades young consumers are still influenced by the COO cue. It is especially important for the international marketing practitioner to know under which conditions the cue is more salient. The implications of the propositions presented here suggest that when dealing with less product-involved young customers, the COO image attached to a company's products is particularly critical. For industry organisations and government initiatives the significant interactions mean that funding used for country- or industry-specific origin branding can be directed towards those youth segments with the highest pay-off. The proposition regarding the interaction effect of product origin congruency on product evaluations suggests that young consumers rely more on the image of the product origin that they associate with the product when they perceive high origin congruence. Thus, the country of origin associated with a product is an important cue that marketers can employ, and understanding under which circumstances its use is more vital increases the chances for successful employment (Josiassen and Harzing 2008). Future research should examine empirically the conjectures made in this article. Future research should also consider investigating the youth segment specifically in developing countries. Another interesting research avenue is to investigate whether the $\mathrm{COO}$ cue is salient for young consumers, and under which contextual circumstances, in a large economy with relatively little foreign trade, such as the USA. In general, research on constructs that may moderate the effect of $\mathrm{COO}$ is a fertile area for future research endeavours.

\section{References}

Ahmed, Sadrudin A, and Alain d'Astous. 1999. "Product-country images in Canada and in the People's Republic of China." Journal of International Consumer Marketing 11 (1): 5.

Ahmed, Sadrudin A, and Alain d'Astous. 2004. "Perceptions of countries as producers of consumer goods: A T-shirt study in China." Journal of Fashion Marketing and Management 8 (2): 187-200. 
Ahmed, Sadrudin A., Alain d'Astous, and Jelloul Eljabri. 2002. "The impact of technological complexity on consumers' perceptions of products made in highly and newly industrialised countries." International Marketing Review 19 (4): 387-407.

Ahmed, Zafar U, James P Johnson, Chew Pei Ling, Tan Wai Fang, and Ang Kah Hui. 2002. "Countryof-origin and brand effects on consumers' evaluations of cruise lines." International Marketing Review 19 (2/3): 279-303.

Ahmed, Zafar U, James P Johnson, Xia Yang, and Chen Kheng Fatt. 2004. "Does country of origin matter for low-involvement products?" International Marketing Review 21 (1): 102-120.

Balabanis, George, and Adamantios Diamantopoulos. 2004. "Domestic Country Bias, Country-ofOrigin Effects, and Consumer Ethnocentrism: A Multidimensional Unfolding Approach." Journal of the Academy of Marketing Science 32 (1): 80-95.

Balabanis, George, Adamantios Diamantopoulos, Rene Dentiste Mueller, and T C Melewar. 2001. "The impact of nationalism, patriotism and internationalism on consumer ethnocentric tendencies." Journal of International Business Studies 32 (1): 157-169.

Balabanis, George, Rene Mueller, and T C Melewar. 2002. "The relationship between consumer ethnocentrism and human values." Journal of Global Marketing 15 (3,4): 7-21.

Baughn, C. C., and Atilla Yaprak. 1993. "Mapping Country-of-Origin Research: Recent Developments and Emerging Avenues." In Product Country Images: Impact and Role in International Marketing. Eds. N. Papadopoulos and L. Heslop. New York: International Business Press.

Beverland, Michael, and Adam Lindgreen. 2002. "Using country of origin in strategy: The importance of context and strategic action." Journal of Brand Management 10 (2): 147-167.

Bilkey, Warren J, and Erik Nes. 1982. "Country-of-origin effects on product evaluations." Journal of International Business Studies 13 (1): 89-100.

Chao, Paul. 2001. "The moderating effects of country of assembly, country of parts, and country of design on hybrid product evaluations." Journal of Advertising 30 (4): 67-82.

Chao, Paul, Gerhard Wuhrer, and Thomas Werani. 2005. "Celebrity and foreign brand name as moderators of country-of-origin effects." International Journal of Advertising 24 (2): 173-191.

Colyer, Edwin. 2005. "Beer brands and homelands." Brandchannel.com.

d'Astous, Alain, and Sadrudin A. Ahmed. 1999. "The importance of country images in the formation of consumer product perceptions." International Marketing Review 16 (2): 108-126.

Day, G. S. 1970. Buyer Attitudes and Brand Choice. New York: Free Press.

Eroglu, Sevgin A., and Karen A. Machleit. 1989. "Effects of Individual and Product-Specific Variables on Utilising Country of Origin as a Product Quality Cue." International Marketing Review 6 (6): 27-52.

Friedman, Hershey H., and Linda Friedman. 1979. "Endorser Effectiveness by Product Type." Journal of Advertising Research 19 (5): 63-71.

Gurhan-Canli, Zeynep, and Durairaj Maheswaran. 2000. "Determinants of country-of-origin evaluations." Journal of Consumer Research 27 (1): 96-108.

Han, C. Min. 1989. "Country Image: Halo Or Summary Construct?" Journal of Marketing Research 26 (2): 222-229.

Haugtvedt, Curtis P., Richard E. Petty, and John T. Cacioppo. 1992. "Need for Cognition and Advertising: Understanding the Role of Personality Variables in Consumer Behavior." Journal of Consumer Psychology 1 (3): 239-260.

Hong, J. W., and G. M Zinkhan. 1995. "Self-concept and advertizing effectiveness: The influence of conruency, conspicuousness, and responsemode." Psychology \& Marketing 12: 53-77.

Johansson, Johny K. 1998. "The Marketing of Nations." Journal of Marketing 62 (3): 148-151.

Johansson, Johny K, Susan P Douglas, and Ikujiro Nonaka. 1985. "Assessing the impact of country of origin on product evaluations: A new methodological perspective." Journal of Marketing Research 22 (4): 388-396.

Johansson, Johny K, Ilkka A Ronkainen, and Michael R Czinkota. 1994. "Negative country-of-origin effects: The case of the new Russia." Journal of International Business Studies 25 (1): 157-169.

Johansson, Johny K. 1989. "Determinants and Effects of the Use of "Made In" Labels." International Marketing Review 6 (1): 47-72. 
Johansson, Johny K., and Israel D. Nebenzahl. 1986. "Multinational Production: Effect on Brand Value." Journal of International Business Studies 17 (3): 101-126.

Josiassen, Alexander, and Anne-Wil Harzing. 2008. "Descending from the Ivory Tower: Reflections on the relevance and future of country-of-origin research." European Management Review 5 (4): 264270.

Josiassen, Alexander, Bryan A. Lukas, and Gregory Whitwell. 2008. "Country-of-Origin Contingencies: Competing Perspectives on Product Familiarity and Product Involvement." International Marketing Review 25 (4): 423-440.

Josiassen, Alexander P., and Ingo O. Karpen. 2007. "The Country-of-Origin Concept: The Historical Approach to Identifying Future Research Challenges." In Australian and New Zealand Marketing Association Conference (ANZMAC) Proceedings. Ed. O. U. Press. Dunedin, New Zealand.

Kamaruddin, Mokhlis, and Othman. 2002. "Ethnocentrism orientation and choice decisions of malaysian consumers." Asia Pacific Journal of Management 2 (2): 222-232.

Kamins, Michael A. 1990. "An Investigation Into The 'Match-Up' Hypothesis In Celebrity Advertizing." Journal of Advertising 19 (1): 4-14.

Kaynak, Erdener, and Ali Kara. 2002. "Consumer perceptions of foreign products: An analysis of product-country images and ethnocentrism." European Journal of Marketing 36 (7/8): 928-949.

Klein, Jill Gabrielle. 2002. "Us versus them, or us versus everyone? Delineating consumer aversion to foreign goods." Journal of International Business Studies 33 (2): 345-358.

Klein, Jill Gabrielle, Richard Ettenson, and Marlene D Morris. 1998. "The animosity model of foreign product purchase: An empirical test in the People's Republic of China." Journal of Marketing 62 (1): 89-100.

Kleppe, Ingeborg Astrid, Nina M Iversen, and Inger G Stensaker. 2002. "Country images in marketing strategies: Conceptual issues and an empirical Asian illustration." Journal of Brand Management 10 (1): 61-74.

Laroche, Michel, Nicolas Papadopoulos, Louise A Heslop, and Mehdi Mourali. 2005. "The influence of country image structure on consumer evaluations of foreign products." International Marketing Review 22 (1): 96-115.

Leclerc, France, Bernd H Schmitt, and Laurette Dube. 1994. "Foreign branding and its effects on product perceptions and attitudes." Journal of Marketing Research 31 (2): 263-270.

Levitt, Theodore. 1983. "The globalization of markets." Harvard Business Review May-June: 92-102.

Li, Zhan G, L William Murray, and Don Scott. 2000. "Global sourcing, multiple country-of-origin facets, and consumer reactions." Journal of Business Research 47 (2): 121-133.

Low, George S., and Ronald A. Fullerton. 1994. "Brands, brand management, and the brand manager system: A critical-historical evaluation." Journal of Marketing Research (JMR) 31 (2): 173.

Maheswaran, Durairaj. 1994. "Country of origin as a stereotype: Effects of consumer expertise and attribute strength on product evaluations." Journal of Consumer Research 21 (2): 354-365.

Misra, Shekhar, and Sharon E. Beatty. 1990. "Celebrity Spokesperson and Brand Congruence: An Assessment of Recall and Affect." Journal of Business Research 21 (2): 159-171.

Mohamad, Osman, Zafar U Ahmed, Earl D Honeycutt Jr, and Taizoon Hyder Tyebkhan. 2000. "Does "made in..." matter to consumers? A Malaysian study of country of origin effect." Multinational Business Review 8 (2): 69-85.

Moon, Byeong-Joon. 2003. "Effects of Consumer Ethnocentrism and Product Knowledge on Consumers' Utilization of Country-of-Origin Information." Advances in Consumer Research 31: 667-673.

Moon, Byeong Joon, and Subhash C Jain. 2001. "Consumer processing of international advertising: The roles of country of origin and consumer ethnocentrism." Journal of International Consumer Marketing 14 (1): 89-109.

Morgan, Ted. 2007. "Eastern Europe: Europe's Advertising Hotspots." In The Financial Times.

Nagashima, Akira. 1970. "A Comparison of Japanese and U.S. Attitudes Toward Foreign Products." Journal of Marketing 34 (1): 68-74.

Nagashima, Akira. 1977. "A comparative "made in" product image survey among Japanese businessmen." Journal of Marketing 41 (3): 95-100. 
Nevett, Terence. 1991. "Historical investigation and the practice of marketing." Journal of Marketing 55 (3): 13-23.

Ohmae, Kenichi. 1995. "Putting global logic first." Harvard Business Review January-February: 119125.

Olson, J. C. 1977. "Price as an informational cue: Effects on product evaluations." In Consumer and Industrial Buying Behaviour. Ed. J. N. S. Arch G. Woodside, and Peter D. Bennett. Amsterdam: North Holland Publishing Company, 267-286.

Osgood, C.E., and P.H. Tannenbaum. 1955. "the Principle of Congruity in Prediction of Attitude Change." Psychological Review 62: 42-55.

Ozsomer, A, and St Cavusgil. 1991. "Country-of-origin effects on product evaluations: A Sequel to Bilkey and Nes Review." Proceedings of the American Marketing Association Conference: 269277.

Papadopoulos, Nicolas, and Louise Heslop. 2002. "Country equity and country branding: Problems and prospects." Journal of Brand Management 9 (4/5): 294.

Pappu, Ravi, Pascale Quester, and Ray Cooksey. 2006. "Consumer-based brand equity and country of origin relationships." European Journal of Marketing 40 (5/6): 696-717.

Parameswaran, Ravi, and R Mohan Pisharodi. 1994. "Facets of country of origin image: An empirical assessment." Journal of Advertising 23 (1): 43-56.

Parameswaran, Ravi, and R Mohan Pisharodi. 2002. "Assimilation effects in country image research." International Marketing Review 19 (2/3): 259-278.

Parameswaran, Ravi, and Attila Yaprak. 1987. "A Cross-National Comparison of Consumer Research Measures." Journal of International Business Studies 18 (1): 35-49.

Petty, Richard E., and John T. Cacioppo. 1984. "Source Factors and the Elaboration Likelyhood Model of Persuasion." Advances in Consumer Research 11 (1): 668-672.

Petty, Richard E., John T. Cacioppo, and David Schumann. 1983. "Central and Peripheral Routes to Advertising Effectiveness: The Moderating Role of Involvement." Journal of Consumer Research 10 (2): $135-146$.

Pharr, Julie M. 2005. "Synthesizing Country-of-Origin Research from the last Decade: Is the concept still Salient in an Era of Global Brands?" Journal of Marketing Theory \& Practice 13 (4): 34-45.

Phau, Ian, and Gerard Prendergast. 2000. "Conceptualizing the country of origin of brand." Journal of Marketing Communications 6 (3): 159-170.

Pisharodi, R Mohan, and Ravi Parameswaran. 1992. "Confirmatory factor analysis of a country-oforigin scale: Initial results." Advances in Consumer Research 19: 706-714.

Pisharodi, R Mohan, and Ravi Parameswaran. 1999. "Temporal stability of country-of-origin image." Proceedings of the American Marketing Association Conference: 229-230.

Roth, Martin S., and Jean B. Romeo. 1992. "Matching Product Category and Country Image Perceptions: A Framework for Managing Country-of-Origin Effects." Journal of International Business Studies 23 (3): 477-497.

Schooler, Robert D. 1965. "Product bias in the Central American common market." Journal of Marketing Research 2 (4): 394-397.

Sharma, Subhash, Terence A Shimp, and Jeonghsin Shin. 1995. "Consumer ethnocentrism: A test of antecedents and moderators." Journal of the Academy of Marketing Science 23 (1): 26-37.

Shimp, Terence A., and Subhash Sharma. 1987. "Consumer Ethnocentrism: Construction and Validation of the CETSCALE." Journal of Marketing Research 24 (3): 280-289.

Sirgy, M. J. 1982. "Self-concept in consumer bhavior: A critical review." Journal of Consumer Research 9: 287-300.

Sirgy, M. J. 1985. "Using self-congruity and ideal congruity to predict purchase motivation." Journal of Business Research 13: 195-206.

Sirgy, M. J. 1986. Self congruity. New York: Praeger.

Strizhakova, Yuliya, Robin A. Coulter, and Linda L. Price. 2008. "Branded Products as a Passport to Global Citizenship: Perspectives from Developed and Developing Countries." Journal of International Marketing 16 (4): 57-85. 
Verlegh, Peeter W J, Jan-Benedict E M Steenkamp, and Matthew T G Meulenberg. 2005. "Country-oforigin in consumer processing of advertizing claims." International Journal of Market Research 22: 127-139.

Winter, Mary. 2004. "The Power of Origins." Marketing: 46-47.

Wong, Chui Yim, Michael J. Polonsky, and Romana Garma. 2008. "The impact of consumer ethnocentrism and country of origin sub-omponents on young chinese consumers' assessments." Asia Pacific Journal of Marketing and Logistics 20 (4): 455-478.

Wong, Nancy, Aric Rindfleisch, and James E Burroughs. 2003. "Do reverse-worded items confound measures in cross-cultural consumer research? The case of the material values scale." Journal of Consumer Research 30 (1): 72-91.

Yaprak, Attila, and Ravi Parameswaran. 1986. "Strategy formulation in multinational marketing: a deductive, paradigm-integrating approach." Advances in International Marketing 1: 21-45. 
